\title{
MEK Inhibitor TAK-733
}

National Cancer Institute

\section{Source}

National Cancer Institute. MEK Inhibitor TAK-733. NCI Thesaurus. Code C84858.

An orally bioavailable small-molecule inhibitor of MEK1 and MEK2 (MEK1/2) with potential antineoplastic activity. MEK inhibitor TAK-733 selectively binds to and inhibits the activity of MEK1/2, preventing the activation of MEK1/2-dependent effector proteins and transcription factors, which may result in the inhibition of growth factor-mediated cell signaling and tumor cell proliferation. MEK1/2 (MAP2K1/K2) are dual-specificity threonine/tyrosine kinases that play key roles in the activation of the RAS/RAF/MEK/ERK pathway and are often upregulated in a variety of tumor cell types. 